\title{
Use of thermally sprayed aluminium (TSA) coatings to protect offshore structures in submerged and splash zones
}

\author{
Berenika SYREK-GERSTENKORN $^{1,2}$, Shiladitya PAUL $^{3,4}$ Alison J DAVENPORT $^{1}$ \\ ${ }^{1}$ School of Metallurgy and Materials, University of Birmingham, Edgbaston, Birmingham, \\ B15 2TT, UK \\ ${ }^{2}$ National Structural Integrity Research Centre (NSIRC), Granta Park, Great Abington, \\ Cambridge, CB21 6AL, UK \\ ${ }^{3}$ TWI Ltd., Granta Park, Great Abington, Cambridge, CB21 6AL, UK, (*corresponding \\ author: shiladitya.paul@twi.co.uk) \\ ${ }^{4}$ Department of Engineering, University of Leicester, Leicester, LE1 7RH, UK
}

\begin{abstract}
:
In this work, the behaviour of arc-sprayed aluminium (1050) coatings was investigated under full artificial seawater immersion and compared with simulated splash zone conditions under droplets of artificial seawater exposed to controlled conditions. To gain a better insight into the mechanism of corrosion of thermally sprayed coatings, tests were also performed on solid 1050 aluminium. Effectiveness of TSA coatings was evaluated using electrochemical techniques and corrosion products were examined by SEM/EDX and Raman spectroscopy. Sulphur containing corrosion products, such as felsobanyaite, were found on the coating as well as on the solid metal. This highlights the importance of using seawater, and not $\mathrm{NaCl}$ solutions, as a corrosive medium simulating marine environment. Moreover, it was observed that cathodic and anodic regions on thermally sprayed coatings were not easily distinguishable, whereas on solid metal, cathodic areas were located in the spreading region, where carbonate corrosion product (dawsonite) was detected. Full immersion studies revealed the need for pre-exposing samples before electrochemical testing, to predict long-term behaviour of the coating in marine service.
\end{abstract}


Keywords:

Thermally sprayed aluminium, thermal spray coatings, cathodic protection, metallic coatings, marine corrosion, aluminium corrosion products

\section{Highlights:}

- The importance of evaluating the behaviour of TSA coatings under both splash and full immersion conditions has been demonstrated

- Sulphur is an important constituent of corrosion products of $\mathrm{Al}$ exposed to artificial seawater

- It takes several days for the corrosion potential of TSA to stabilise, therefore pre-exposure of the sample is needed before performing electrochemical testing 


\section{Introduction}

Clean energy sources, such as offshore wind power, are being more and more of recent as a consequence of efforts aimed at the minimisation of the environmental footprint of carbon dioxide produced by the combustion of fossil fuels, which is blamed for its contribution to the global warming. According to the Crown Estate annual report [1], in 2017 over 6\% of the UK's electricity demand was covered by offshore wind farms, which reduced the UK's CO2 emission by 8.6 million tonnes. It is expected that development of offshore wind turbines will accelerate even further, and larger and more distant offshore wind turbines will be built [2]. Currently most of offshore wind turbines are based on a monopile foundation made of a steel pipe which outer diameter is usually between 4 and 6 meters [3]. Carbon steel is the material of choice because of its high strength and weldability, combined with relatively low cost. However, it is prone to corrosion in harsh seawater environment and therefore relevant corrosion mitigation methods must be applied.

External corrosion of offshore wind turbine foundations is relatively well understood and controlled by a combination of cathodic protection (for submerged parts of the structure) and protective coatings (mainly for atmospheric and splash zones), whereas internal corrosion is still a challenge due to many factors, such as undesirable ingress of seawater resulting from problems with inadequate sealing methods and varying aeration as well as microbiological activities [4].

A promising candidate for an external as well as an internal corrosion mitigation method is a thermally sprayed aluminium (TSA) coating. Unlike organic coatings, TSA provides protection not only when the coating remains intact, but also in case of damage [5]. Even if substrate steel is partially exposed, for instance as a result of a mechanical damage, TSA provides sacrificial protection working as an evenly distributed anode [6] due to its position in 
the galvanic series - being more electronegative in respect to steel when immersed in seawater. Moreover, in comparison to traditional galvanic anodes, TSA does not have to be replaced periodically and does not significantly increase the weight of the structure.

The high resistance to corrosion in aqueous media of TSA coatings is associated with its passive nature [7]. A passive oxide film, which forms on the surface of aluminium according to equation 2 works as an electrical insulator [8] [9]. It prevents the movement of electrons (produced during anodic dissolution of the metal) from the metal to the oxide/solution interface, which results in the inhibition of cathodic reactions on the coating. The protective passive film is stable in the $\mathrm{pH}$ range of $\sim 4$ to 9 . However, in the presence of aggressive ions, such as chlorine, local breakdowns of the passive layer are likely to occur - leading to a localised form of corrosion called pitting.

Corrosion of aluminium in aerated seawater environment (of $\mathrm{pH} 7.5$ - 8.4) involves two simultaneous reactions: (i) anodic:

and (ii) cathodic:

To date, TSA has been successfully utilised as a means of corrosion control mainly in the oil and gas sector. Its performance, mostly under full immersion conditions, has been proven in both - laboratory and field studies, but the behaviour under splash zone and marine atmospheric conditions has not yet been fully explored. The aim of this paper is to compare the behaviour of TSA coating under full immersion conditions with the exposure to an 
artificial seawater droplet. To gain a better insight into the mechanisms of corrosion of thermally sprayed coatings, tests were also performed on solid aluminium.

\section{Experimental}

\subsection{Materials}

Carbon steel plates (Parker Steel - Tab.1) and glass slides were used as substrate materials. Before spraying, steel and glass slides were prepared by blasting with 36 mesh alumina abrasive blasting grit. The substrates were then sprayed with commercially pure aluminium (99.5wt\% - Table, Metallisation Ltd.) using twin wire arc spraying method (ARC 140 pistol Metallisation Ltd.). Spraying parameters are provided in Tab.2.

\subsection{Material characterisation}

Material characterisation was performed with an optical microscope (Leica DFC420) and a Scanning Electron Microscope (SEM) (Jeol 6060LV). A $15 \mathrm{kV}$ accelerating voltage and 10 mm working distance were used for EDX analysis.

The roughness of the thermally sprayed aluminium layer was also determined using an Alicona Infinite Focus SL 3D surface profilometer and associated IF Measure Suite software. Roughness measurements were performed in compliance with BS EN ISO 4288:1998:

“Geometric product specification (GPS). Surface texture. Profile method: Rules and procedures for the assessment of surface texture" [10].

\subsection{Splash zone experiments with droplets of artificial seawater}

\subsubsection{Sample preparation}

Three types of samples were used for the experiments, namely 1050-H14 Al sheet (Smiths Metal Centres Ltd.), TSA deposited on glass slides, and TSA deposited on carbon steel plates. Prior to the tests, samples were washed with methanol and left to dry in a desiccator. 


\subsubsection{Experimental procedure}

Before tests, two desiccators with saturated aqueous salt solutions of $\mathrm{KCl}$ and $\mathrm{K}_{2} \mathrm{SO}_{4}$ were pre-pared to obtain the relative humidity $(\mathrm{RH})$ of $84 \%$ and $97 \%$, respectively, in accordance to ASTM E104-02 standard.

Arrays of artificial seawater (ASW) ASTM D1141-98 droplets of volumes 1.5 and 2.5 uL were deposited onto samples using a micropipette. Samples were then put inside the sealed desiccators, which were kept at constant temperature of $30^{\circ} \mathrm{C}$ inside an atmospheric chamber for 2 weeks. After the completion of the tests, samples were taken out from the desiccators and rinsed with deionised water and methanol.

\subsubsection{Characterisation of corrosion products}

Identification of corrosion products formed under "typical" droplets was performed via Raman spectroscopy (Renishaw InVia spectrometer) using an excitation wavelength of 488 $\mathrm{nm}$ with $\sim \mathrm{mW}$ focused through a 20x working distance objective. All measurements were performed with $100 \%$ laser power during 10s exposure time and 2 accumulations. The range of collected Raman shift was between $200 \mathrm{~cm}^{-1}$ and $1600 \mathrm{~cm}^{-1}$. The pre-processing of the data involved baseline subtraction and cosmic ray removal using $\mathrm{WiRE}^{\mathrm{TM}}$ software.

Raman maps were produced via direct classical least square analysis (DCLS) performed using control standards taken from RRUFF database [11]. Subsequently, bitmap images were generated which were then used to create the plots of Raman shifts versus intensity using a Matlab script [12]. The data used for the generation of plots were averaged and normalized. 


\subsection{Full immersion experiments}

\subsubsection{Sample preparation}

Before immersion in ASW, the back and the sides of the samples were covered with 3 layers of stop-off lacquer 45 (MacDermid). The area of TSA deposited on steel exposed to seawater was approximately $13.1 \mathrm{~cm}^{2}$ and TSA deposited on glass slide was approximately $10.4 \mathrm{~cm}^{2}$.

\subsubsection{Experimental procedure}

For electrochemical measurements a typical 3 electrodes systems consisting of an $\mathrm{Ag} / \mathrm{AgCl}$ reference electrode, a Pt/Ti counter electrode, and a sample as the working electrode. Measurements of the open circuit potential (OCP) and linear polarisation resistance (LPR) scans were performed using a Biologic VMP-300 potentiostat. Polarisation curves were generated using an IVIUM potentiostat (IVIUM Technologies). The OCP was monitored for 32 days and LPR scans $( \pm 10 \mathrm{mV}$ vs OCP) were conducted every 6 hours.

3. Results and discussion

\subsection{Behaviour of TSA in the splash zone}

Fig. 1 presents secondary electron SEM images of the corroded surface of the as-received 1050 aluminium sheet sample after a 2 -week exposure to ASW at $\mathrm{RH}=84 \pm 4 \%$ and $\mathrm{T}=30 \pm 1^{\circ} \mathrm{C}$, after the removal of the droplet. One can notice several morphologies of corrosion products formed on the surface of the metal. Primarily, very thin corrosion products can be observed under the main body of the droplet, but several agglomerations of dense, mound-like corrosion products are visible outside the droplet, too. 
To identify the corrosion products formed under the droplet, EDX mapping was performed.

The results of the analysis are shown in Fig. 2. One can notice that chlorine as well as sodium were detected outside the main body of the droplet. However, chlorine was only found in places where the dense corrosion products were formed, whereas sodium was uniformly distributed around the edge of the droplet. Sulphur, on the other hand, was only detected inside the droplet.

Analysis performed using Raman spectroscopy revealed the presence of felsobanyaite $\left(\mathrm{Al}_{4}\left(\mathrm{SO}_{4}\right)(\mathrm{OH})_{10} \cdot 4 \mathrm{H}_{2} \mathrm{O}\right)$ in the main body of the droplet, and dawsonite $\left(\mathrm{NaAlCO}_{3}(\mathrm{OH})_{2}\right)$ outside the droplet, which can be seen in Fig. 2. EDX analysis confirmed the presence of sulphur in felsobanyaite and sodium in dawsonite. Aluminium sulphate hydrates are common corrosion products on aluminium exposed to marine atmosphere [13] [14] [15]. Sulphates present in the solution are adsorbed on aluminium oxide layer [16] and converted into corrosion products.

Felsobanyaite (also known as basaluminite), which precipitates at $\mathrm{pH}>4.5-5.0$ [17] in accordance to the following equation [18]:

was also detected by S.Glanvill on aluminium under a droplet of artificial seawater droplet [19]. Other aluminium sulphates with similar Raman spectra are shown in Tab.3.

Spreading of droplets at high humidity has been reported by others, mainly on zinc [26] [27] [28] [29], copper [30] [31] [32] and steel [28] [33]. The presence of dawsonite in the spreading region is associated with the development of cathodic regions near the droplet edge, where the water layer thickness is the lowest, and hence the diffusion of oxygen is facilitated. When cathodic reactions proceed, $\mathrm{OH}^{-}$ions are being produced in accordance to equation (3). Aluminium oxides are soluble in alkaline solutions, which leads to dissolution of the passive 
film and a change in the interfacial energy. As a result, a $\mathrm{pH}$ gradient is established within the droplet, leading to a change in the interfacial energy between the metal and the electrolyte, resulting in the droplet spreading [30]. To balance the negative charge, cations present in the solution (for example $\mathrm{Na}^{+}$) are attracted to the spreading region, which has easy access to carbon dioxide. Since precipitation of dawsonite requires alkaline conditions [34], with $\mathrm{pH}$ 10.3 being the most favourable [35], it could be assumed, that alkaline conditions were present in the spreading region which facilitated precipitation of dawsonite :

$$
\mathrm{Al}^{3+}+2 \mathrm{OH}^{-}+\mathrm{Na}^{+}+\mathrm{HCO}_{3}^{-} \rightarrow \mathrm{NaAlCO}_{3}(\mathrm{OH})_{2}+\mathrm{H}^{+}
$$

Dawsonite was also detected by F.Schaller et al. [36] on aluminium after exposure to an $\mathrm{NaCl}$ droplet and $80 \% \mathrm{RH}$. Moreover, carbonate deposits were also observed on aluminium after exposure to $\mathrm{NaCl}$, by D. B. Blucher at al. [37] and [38].

EDX analysis of corrosion products (Figure 19) formed under the $1.5 \mu \mathrm{L}$ droplet of ASW on TSA deposited on glass slide during 2-week exposure to $\mathrm{RH}=84 \pm 4 \%$ and $\mathrm{T}=30 \pm 1{ }^{\circ} \mathrm{C}$ revealed the presence of chlorine, sulphur, and oxygen. Corrosion products were dense and formed under the main body of the droplet.

Raman spectroscopy analysis (Figure 20) indicated the presence of felsobanyaite, however the additional peak at $1002 \mathrm{~cm}^{-2}$ suggests the possibility of the formation of some other sulphate product like for example aluminite $\left(\mathrm{Al}_{2}\left(\mathrm{SO}_{4}\right)(\mathrm{OH})_{4} \cdot 7 \mathrm{H}_{2} \mathrm{O}\right)$ or alunogen $\left(\mathrm{Al}_{2}\left(\mathrm{SO}_{4}\right)_{3} \cdot 17 \mathrm{H}_{2} \mathrm{O}\right)$.

Similarly, Raman spectroscopy combined with EDX analysis of corrosion products formed on TSA-coated steel sample revealed the possibility of the formation of felsobanyaite. One can notice the lack of dawsonite or any similar carbonates on TSA samples. The possible reason for this could be that the droplets do not spread on TSA samples because of the very rough surface. Since the spreading of the droplet on smooth solid metal surface is associated with the development of separate anodic and cathodic regions, it can be assumed that anodic and cathodic reactions were not so clearly separated on TSA coatings. The roughness of the 
coating (TSA on steel is as follows: $\mathrm{Ra}=26.5 \mu \mathrm{m}$, TSA on glass: $\mathrm{Ra}=24.0 \mu \mathrm{m}$ ), which influences the wettability of the droplet [39] [40], the presence of porosity within the coating or the presence of a thicker oxide layer.

\subsection{Behaviour of TSA in full immersion}

The OCP of TSA deposited on steel and on a glass slide was monitored for 32 days in artificial seawater at $25^{\circ} \mathrm{C}$. The results are shown in Fig. 11. Noticeably, during the whole test the potential of TSA deposited on a glass slide was higher than TSA deposited on steel. One possible explanation is that the steel substrate is thermally conductive, so the deposited layer may have cooled more quickly, forming a thinner oxide film, leading to a higher passive current density and thus a lower OCP.

Polarisation resistance (Rp) data (Fig.12 and Fig.13) illustrate significantly different behaviour of the coating deposited on steel and on glass. For TSA-coated steel, Rp values are initially low, indicating higher corrosion rates, however Rp values progressively increase with immersion time, indicating that corrosion rates decrease over time (Fig.13), probably due to the development of thicker passivating oxide layers and corrosion products blocking of pores in the coatings. In the latter case, Rp values were initially high and decreased during approximately 5 days of immersion. After 5 days they started to rise. Measurement of the corrosion potential reveals that during the initial days of immersion the OCP decreased, suggesting that decreasing $\mathrm{Rp}$ values could be related to dissolution of air-formed oxide layers. When oxide layers dissolve, corrosion rates increase (Fig.13), and once new waterborn oxide layers start to form, corrosion rates slow down and Rp values start to increase.

In the case of the coating on steel, a steady decrease in corrosion rates is likely associated with interconnected porosity of the coating. At the beginning of the immersion, seawater can 
penetrate the coating, so self-corrosion of $\mathrm{Al}$ (due to sacrificial actions) is significant. Once pores are filled with corrosion products and calcareous deposits, corrosion decelerates.

Both Ecorr and Rp values suggest that steady state of TSA is not reached for at least several days of immersion. This can be also seen from Tafel scans performed after different immersion times in artificial seawater (Fig.14). Tafel scans performed after two days showed that varying the substrate caused significant differences in Ecorr and i. After 7 days the effect of the substrate reduced and Ecorr and i converged. This highlights the importance of sample pre-exposure before conducting any polarisation measurements.

Analysis of corrosion products formed on TSA-coated steel sample after a 32-day immersion which was conducted using Raman spectroscopy revealed the presence of several deposits (Fig.15). The signal coming from the spot measurement conducted in region B matches the control spectrum of felsobanyaite. Signals A and C seem to be a mixture of felsobanyaite and hydrotalcite $\left(\mathrm{Mg}_{6 \mathrm{Al}_{2}}\left(\mathrm{CO}_{3}\right)(\mathrm{OH})_{16} \cdot 4 \mathrm{H}_{2} \mathrm{O}\right)$, whereas signal D matches control spectrum of aragonite $\left(\mathrm{CaCO}_{3}\right)$. Precipitation of hydrotalcite was also observed by other researchers, for example H. Ding et al. [41] detected an Al-Mg hydrotalcite-like compound on an aluminium matrix composite and on 6061-T6 Al after immersion in seawater environments. The authors suggested the formation of the precipitates via the induced hydrolysis process [42] at $\mathrm{pH}$ range: $4-8.5$. in which first $\mathrm{Al}$ hydroxide gel is produced and then $\mathrm{Mg}^{2+}$ as well as $\mathrm{CO}_{3}{ }^{2-}$ ions are incorporated into it and recrystallised. The same mechanism was proposed by C.E Austing et al. [43] who detected hydrotalcite on aluminium in desalination plants.

Aragonite is a well-known calcareous deposit which forms in seawater on cathodically protected steel [44][45][46]. It precipitates in $\mathrm{pH}$ range 7.3-8.7 [47], which is close to the $\mathrm{pH}$ of ASTM seawater ( $\mathrm{pH}$ 8.2). The presence of sulphur- and magnesium-containing corrosion products indicates the need for using seawater to test the corrosion performance of TSA. 
Solutions of $\mathrm{NaCl}$, commonly used as a substitute of seawater, may not be representative of the real seawater environment.

\section{Conclusions}

The following conclusions can be drawn from the work presented in this paper:

1. Examination of corrosion products formed on solid 1050 AA and TSA (1050 AA) under a droplet of artificial seawater revealed the presence of sulphur containing products such as felsobanyaite and /or aluminite in the main body of the droplet. On $1050 \mathrm{Al}$ sheet, dawsonite has formed in well-defined spreading region, where the cathodic reactions take place, whereas on TSA anodic and cathodic reactions are not clearly separated

2. Sulphur (from the sulphates in seawater) plays an important role in corrosion processes, therefore the use of aqueous solutions of $\mathrm{NaCl}$ as a substitute for seawater for the evaluation of corrosion performance of TSA coatings in marine environments should be avoided, as it could lead to results not representative of seawater exposure.

3. The distribution of cathodic and anodic regions on thermally sprayed coatings is significantly different than on solid metal, probably due to the difference in surface morphology. On solid metal, dawsonite was detected in the well-defined spreading region, whereas on TSA mostly sulphur-containing corrosion products were found in the main body of the droplet.

4. It takes several days for the corrosion potential of Al to stabilise, therefore preexposure of the sample is needed before performing electrochemical testing. Short-term laboratory tests (a few hours) may not be representative of long-term behaviour of TSA in marine service.

5. Felsobanyaite, hydrotalcite as well as aragonite have been detected on TSA on a steel sample after full immersion in artificial seawater using Raman spectroscopy. 


\section{Acknowledgments}

The authors gratefully acknowledge financial support from the Centre for Doctoral Training in Innovative Metal Processing (IMPaCT) funded by the UK Engineering and Physical Sciences Research Council (EPSRC), grant reference EP/L016206/1”. This publication was made possible by the sponsorship and support of Lloyd's Register Foundation, a charitable foundation helping to protect life and property by supporting engineering-related education, public engagement and the application of research. The work was enabled through, and undertaken at, the National Structural Integrity Research Centre (NSIRC), a post-graduate engineering facility for industry-led research into structural integrity established and managed by TWI through a network of both national and international Universities

The authors would like to thank Dr Sarah Glanvill and Mr George Rowley for their help with Raman spectroscopy. 


\section{References}

[1] The Crown Estate, Offshore Wind - Operational report 2017, n.d. doi:10.1016/B978-012-410422-8.00003-0.

[2] B.B. Jensen, Specifying Corrosion Protection for the Offshore Wind Turbine Industry, in: Corros. 2017, NACE International, 2017: p. Paper No 9091.

[3] M.J. Kaiser, B.F. Snyder, Offshore Wind Energy Cost Modeling: Installation and Decommissioning, Springer Science \& Business Media, 2012. doi:10.1007/978-14471-2488-7.

[4] A.R. Black, T. Mathiesen, L.R. Hilbert, Corrosion protection of offshore wind foundations, NACE Int. Houston, TX, USA. (2005).

[5] Z. Glogovië, V. Alar, Z. Kožuh, I. Stojanovië, S. Kralj, Corrosion properties of thermal sprayed aluminium (TSA) coatings deposited by powder flame spraying, Materwiss. Werksttech. 42 (2011) 224-228. doi:10.1002/mawe.201100718.

[6] N. Ce, S. Paul, The Effect of Temperature and Local pH on Calcareous Deposit Formation in Damaged Thermal Spray Aluminum (TSA) Coatings and Its Implication on Corrosion Mitigation of Offshore Steel Structures, Coatings. 7 (2017) 52. doi:10.3390/coatings 7040052 .

[7] L. Garrigues, N. Pebere, F. Dabosi, An investigation of the corrosion inhibition of pure aluminum in neutral and acidic chloride solutions, Electrochim. Acta. 41 (1996) 12091215. doi:10.1016/0013-4686(95)00472-6.

[8] J.R. Davis, Corrosion of aluminium and aluminium alloys, ASM International, 1999.

[9] M.C. Reboul, B. Baroux, Metallurgical aspects of corrosion resistance of aluminium alloys, Mater. Corros. 62 (2011) 215-233. doi:10.1002/maco.201005650.

[10] British Standards Institution, BS EN ISO 4288, 1998: Geometric product specification (GPS). Surface texture. Profile method: Rules and procedures for the assessment of surface texture, 1998.

[11] B. Lafuente, R.T. Downs, H. Yang, N. Stone, The power of databases: the RRUFF project, W. De Gruyter, 2015.

[12] G. Rowley, Raman averaging from WiRE, (2018). https://uk.mathworks.com/matlabcentral/fileexchange/65909-raman-averaging-fromwire?s_tid=gn_loc_drop\#feedbacks (accessed September 16, 2018).

[13] R.E. Lobnig, D.J. Siconolfi, J. Maisano, G. Grundmeier, H. Streckel, R.P. Frankenthal, M. Stratmann, J.D. Sinclair, Atmospheric Corrosion of Aluminum in the Presence of Ammonium Sulfate Particles, J. Electrochem. Soc. 143 (1996) 1175-1182.

doi:10.1149/1.1836615. 
[14] T.E. Graedel, Corrosion mechanisms for aluminum exposed to the atmosphere, J. Electrochem. Soc. 136 (1989) 204C-212C. doi:10.1149/1.2096869.

[15] J.J. Friel, Atmospheric corrosion products on aluminium, zinc, and aluminium-zinc metallic coatings, Corrosion. 42 (1986) 422-426. doi:10.5006/1.3584923.

[16] A. Kolics, J.C. Polkinghorne, A. Wieckowski, Adsorption of sulfate and chloride ions on aluminum, Electrochim. Acta. 43 (1998) 2605-2618. doi:10.1016/S00134686(97)10188-8.

[17] J.S. España, The Behavior of Iron and Aluminum in Acid Mine Drainage: Speciation, Mineralogy, and Environmental Significance, in: T.M. Letcher (Ed.), Thermodyn. Solubility Environ. Issues, Elsevier, 2007: pp. 137-149. doi:10.1016/B978-0444527073/50009-4.

[18] C. Falagán, I. Yusta, J. Sánchez-España, D.B. Johnson, Biologically-induced precipitation of aluminium in synthetic acid mine water, Miner. Eng. 106 (2017) 7985. doi:10.1016/j.mineng.2016.09.028.

[19] S. Glanvill, Atmospheric corrosion of AA2024 in ocean water environments, $\mathrm{PhD}$ Thesis, Univ. Birmingham. (2018).

[20] R.L. Frost, A. López, R. Scholz, L. Wang, A Raman and infrared spectroscopic study of the sulphate mineral aluminite A12(SO4)(OH)4 7H2O, Spectrochim. Acta Part A Mol. Biomol. Spectrosc. 148 (2015) 232-236. doi:10.1016/j.saa.2015.04.011.

[21] F. Košek, A. Culka, V. Žáček, F. Laufek, R. Škoda, J. Jehlička, Native alunogen: A Raman spectroscopic study of a well-described specimen, J. Mol. Struct. 1157 (2018) 191-200. doi:10.1016/j.molstruc.2017.12.021.

[22] V. Hurai, M. Huraiová, M. Slobodník, R. Thomas, Geofluids Developments in Microthermometry, Spectroscopy, Thermodynamics, and Stable Isotopes, Elsevier, 2015. doi:10.1016/C2014-0-03099-7.

[23] R.L. Frost, J.M. Bouzaid, Raman spectroscopy of dawsonite $\mathrm{NaAl}(\mathrm{CO} 3)(\mathrm{OH}) 2$, J. Raman Spectrosc. 38 (2007) 873-879. doi:10.1002/jrs.1733.

[24] Z. Tomić, P. Makreski, B. Gajić, Identification and spectra-structure determination of soil minerals: Raman study supported by IR spectroscopy and x-ray powder diffraction, J. Raman Spectrosc. 41 (2010) 582-586. doi:10.1002/jrs.2476.

[25] J.E. Olszówka, R. Karcz, E. Bielańska, J. Kryściak-Czerwenka, B.D. Napruszewska, B. Sulikowski, R.P. Socha, A. Gaweł, K. Bahranowski, Z. Olejniczak, E.M. Serwicka, New insight into the preferred valency of interlayer anions in hydrotalcite-like compounds: The effect of Mg/Al ratio, Appl. Clay Sci. 155 (2018) 84-94. doi:10.1016/j.clay.2018.01.013.

[26] I.S. Cole, T.H. Muster, S.A. Furman, N. Wright, A. Bradbury, Products Formed during the Interaction of Seawater Droplets with Zinc Surfaces: I. Results from 1- and 2.5-Day Exposures, J. Electrochem. Soc. 155 (2008) C244-C255. doi:10.1149/1.2845075. 
[27] Z.Y. Chen, D. Persson, C. Leygraf, Initial NaCl-particle induced atmospheric corrosion of zinc - Effect of CO2 and SO2, Corros. Sci. 50 (2008) 111-123.

doi:10.1016/j.corsci.2007.06.005.

[28] A. Nazarov, D. Thierry, Rate-determining reactions of atmospheric corrosion, in: Electrochim. Acta, 2004: pp. 2717-2724. doi:10.1016/j.electacta.2004.01.066.

[29] A.K. Neufeld, I.S. Cole, A.M. Bond, S.A. Furman, The initiation mechanism of corrosion of zinc by sodium chloride particle deposition, Corros. Sci. 44 (2002) 555572. doi:10.1016/S0010-938X(01)00056-7.

[30] E.J. Schindelholz, H. Cong, C.F. Jove-Colon, S. Li, J.A. Ohlhausen, H.K. Moffat, Electrochemical aspects of copper atmospheric corrosion in the presence of sodium chloride, Electrochim. Acta. 276 (2018) 194-206. doi:10.1016/j.electacta.2018.04.184.

[31] Z.Y. Chen, D. Persson, A. Nazarov, S. Zakipour, D. Thierry, C. Leygraf, In Situ Studies of the Effect of $\mathrm{CO} 2$ on the Initial NaCl-Induced Atmospheric Corrosion of Copper, J. Electrochem. Soc. 152 (2005) B342-B351. doi:10.1149/1.1984448.

[32] Z.Y. Chen, D. Persson, F. Samie, S. Zakipour, C. Leygraf, Effect of Carbon Dioxide on Sodium Chloride-Induced Atmospheric Corrosion of Copper, J. Electrochem. Soc. 152 (2005) B502-B511. doi:10.1149/1.2098327.

[33] T. Tsuru, K.I. Tamiya, A. Nishikata, Formation and growth of micro-droplets during the initial stage of atmoshperic corrosion, Electrochim. Acta. 49 (2004) 2709-2715. doi:10.1016/j.electacta.2004.01.032.

[34] W. Chesworth, Laboratory Synthesis of Dawsonite and its Natural Occurrences, Nat. Phys. Sci. 231 (1971) 40-41. doi:10.1038/229560a0.

[35] X. Zhang, Z. Wen, Z. Gu, X. Xu, Z. Lin, Hydrothermal synthesis and thermodynamic analysis of dawsonite-type compounds, J. Solid State Chem. 177 (2004) 849-855. doi:10.1016/j.jssc.2003.09.019.

[36] R.F. Schaller, C.F. Jove-Colon, J.M. Taylor, E.J. Schindelholz, The controlling role of sodium and carbonate on the atmospheric corrosion rate of aluminum, Npj Mater. Degrad. 1 (2017). doi:10.1038/s41529-017-0020-3.

[37] D.B. Blücher, J.-E. Svensson, L.-G. Johansson, The NaCl-Induced Atmospheric Corrosion of Aluminum. The influence of Carbon Dioxide and Temperature., J. Electrochem. Soc. 150 (2003) B93-B98. doi:10.1149/1.1545456.

[38] D.B. Blücher, J.-E. Svensson, L.-G. Johansson, The influence of CO2, AlCl3·6H2O, $\mathrm{MgCl} 2 \cdot 6 \mathrm{H} 2 \mathrm{O}, \mathrm{Na} 2 \mathrm{SO} 4$ and $\mathrm{NaCl}$ on the atmospheric corrosion of aluminum, Corros. Sci. 48 (2006) 1848-1866. doi:10.1016/j.corsci.2005.05.027.

[39] D. Quéré, Wetting and Roughness, Annu. Rev. Mater. Res. 38 (2008) 71-99. doi:10.1146/annurev.matsci.38.060407.132434.

[40] K.T. Hong, H. Imadojemu, R.L. Webb, Effects of oxidation and surface roughness on 
contact angle, Exp. Therm. Fluid Sci. 8 (1994) 279-285. doi:10.1016/08941777(94)90058-2.

[41] H. Ding, G.A. Hawthorn, L.H. Hihara, Inhibitive Effect of Seawater on the Corrosion of Particulate-Reinforced Aluminum-Matrix Composites and Monolithic Aluminum Alloy, J. Electrochem. Soc. 156 (2009) C352-C359. doi:10.1149/1.3190521.

[42] R.M. Taylor, The rapid formation of crystalline double hydroxy salts and other compounds by controlled hydrolysis, Clay Miner. 19 (1984) 591-603. doi:10.1180/claymin.1984.019.4.06.

[43] C.E. Austing, A.M. Pritchard, N.J.M. Wilkins, The formation and properties of Al/Mg scales on Al heat- exchange surfaces in desalination plant, Desalination. 12 (1973) 251-272. doi:10.1016/S0011-9164(00)82076-7.

[44] Y. Yang, J.D. Scantlebury, E. V. Koroleva, A Study of Calcareous Deposits on Cathodically Protected Mild Steel in Artificial Seawater, Metals. 5 (2015) 439-456. doi:10.3390/met5010439.

[45] C. Deslouis, D. Festy, O. Gil, G. Rius, S. Touzain, B. Tribollet, Characterization of calcareous deposits in artificial sea water by impedances techniques: I.-Deposit of CaCO3 without $\mathrm{Mg}(\mathrm{OH}) 2$, Electrochim. Acta. 43 (1998) 1891-1901. doi:10.1016/S0013-4686(97)00303-4.

[46] C. Barchiche, C. Deslouis, O. Gil, P. Refait, B. Tribollet, Characterisation of calcareous deposits by electrochemical methods: Role of sulphates, calcium concentration and temperature, Electrochim. Acta. 49 (2004) 2833-2839. doi:10.1016/j.electacta.2004.01.067.

[47] W. Smith, S. Paul, Natural Deposit Coatings on Steel during Cathodic Protection and Hydrogen Ingress, Coatings. 5 (2015) 816-829. doi:10.3390/coatings5040816. 
Table 1. Chemical composition of aluminium and steel

\begin{tabular}{|l|l|l|l|l|l|l|l|l|l|l|l|l|l|}
\hline $\begin{array}{c}\text { Element } \\
\text { wt\% } \\
\text { Material }\end{array}$ & Si & Fe & Cu & Mn & Mg & Zn & Ti & Al & C & P & S & V & N \\
$\begin{array}{l}1050-H 14 \\
\text { sheet }\end{array}$ & 0.04 & 0.36 & 0.001 & 0.003 & 0.000 & 0.001 & 0.009 & Bal. & - & - & - & - & - \\
\hline $\begin{array}{l}99.95 \% \mathrm{Al} \\
\text { wire }\end{array}$ & 0.03 & 0.12 & $<0.01$ & $<0.01$ & $<0.01$ & $<0.01$ & $<0.01$ & Bal. & - & - & - & - & - \\
\hline $\begin{array}{l}\text { S355JR } \\
\text { Steel }\end{array}$ & 0.390 & Bal. & - & 1.39 & - & - & - & - & 0.12 & 0.14 & 0.019 & 0.065 & 0.003 \\
\hline
\end{tabular}


Table 2. Spraying parameters

\begin{tabular}{|c|c|c|c|c|c|c|c|}
\hline & $\begin{array}{c}\text { Wire } \\
\text { size } \\
{[\mathrm{mm}]}\end{array}$ & $\begin{array}{c}\text { Air } \\
\text { pressure } \\
{[\mathrm{bar}]}\end{array}$ & $\begin{array}{c}\text { Stand-off } \\
{[\mathrm{mm}]}\end{array}$ & $\begin{array}{c}\text { Increment } \\
\text { step } \\
{[\mathrm{mm}]}\end{array}$ & $\begin{array}{c}\text { Horizonta } \\
1 \text { traverse } \\
{[\mathrm{mm} / \mathrm{s}]}\end{array}$ & $\begin{array}{c}\text { Current } \\
{[\text { Amps }]}\end{array}$ & $\begin{array}{c}\text { Spraying } \\
\text { Angle }\end{array}$ \\
\hline $\begin{array}{c}\text { TSA on steel } \\
2.3\end{array}$ & 5 & 125 & 10 & 400 & 200 & 90 \\
\hline $\begin{array}{c}\text { TSA on } \\
\text { glass }\end{array}$ & 2.3 & 5 & 300 & 10 & 500 & 200 & 90 \\
\hline
\end{tabular}


Table 3. Chemical compositions and Raman shift of detected and possible substances which may have formed on TSA coatings and solid metal under droplets of ASW

\begin{tabular}{|c|c|c|c|}
\hline Name & Formula & Raman shift $\left(\mathrm{cm}^{-1}\right)$ & Ref. \\
\hline Aluminite & $\mathrm{Al}_{2}\left(\mathrm{SO}_{4}\right)(\mathrm{OH})_{4} \cdot 7 \mathrm{H}_{2} \mathrm{O}$ & $\begin{array}{l}460,494,575,607,631,642,680 \\
993,1069,1094,1136\end{array}$ & [20] \\
\hline Alunogen & $\mathrm{Al}_{2}\left(\mathrm{SO}_{4}\right)_{3} \cdot 17 \mathrm{H}_{2} \mathrm{O}$ & $\begin{array}{l}138,155,180,310,338,415,445,470,528 \\
614,992,1066,1089,1124,1132\end{array}$ & [21] \\
\hline $\begin{array}{l}\text { Aluminium } \\
\text { sulphate }\end{array}$ & $\mathrm{Al}_{2}\left(\mathrm{SO}_{4}\right)_{3} \cdot 18 \mathrm{H}_{2} \mathrm{O}$ & $617,972,988,1127$ & [22] \\
\hline \multirow[t]{2}{*}{ Dawsonite } & \multirow[t]{2}{*}{$\operatorname{NaAl}\left(\mathrm{CO}_{3}\right)(\mathrm{OH})_{2}$} & $\begin{array}{l}152,191,389,519,590,824,897,1091, \\
1506,3252,3283\end{array}$ & [22] \\
\hline & & $189,260,587,1090,1065,1505,3282,3250$ & [23] \\
\hline Aragonite & $\mathrm{CaCO}_{3}$ & $147,174,200,252,698,1080,1110$ & [24] \\
\hline Hydrotalcite & $\mathrm{Mg}_{6} \mathrm{Al}\left(\mathrm{CO}_{3}\right)(\mathrm{OH})_{16} \cdot 4 \mathrm{H}_{2} \mathrm{O}$ & $467,547,680,717,1048,1068,1305,1480$ & [25] \\
\hline
\end{tabular}




\section{List of figure captions}

Figure 1. Secondary electron SEM images of as-received $1050 \mathrm{Al}$ sheet after 2-week exposure to $1.5 \mu \mathrm{L}$ droplet of $\mathrm{ASW}$ and $\mathrm{RH}=84 \pm 4 \%$ and $\mathrm{T}=30 \pm 1^{\circ} \mathrm{C}$; (a) view of the whole droplet, (b) and (c) magnified images of the boxed areas from (a) showing morphology of the corrosion products

Figure 2. Image of corroded as-received $1050 \mathrm{Al}$ sample after 2-week exposure to $1.5 \mu \mathrm{L}$ droplet of ASW and $\mathrm{RH}=84 \pm 4 \%$ and $\mathrm{T}=30 \pm 1{ }^{\circ} \mathrm{C}$; EDX maps of sulphur, oxygen, sodium, magnesium, chlorine and carbon; Raman maps of felsobanyaite/aluminite and dawsonite; SEM and optical microscope images of the corroded region under the droplet

Figure 3. Comparison of the measured Raman spectrum (averaged and baseline corrected) formed on the as received $1050 \mathrm{Al}$ sample after 2-week exposure to $1.5 \mu \mathrm{L}$ droplet of ASW and $\mathrm{RH}=84 \pm 4 \%$ and $\mathrm{T}=30 \pm 1{ }^{\circ} \mathrm{C}$ and standard spectrum of felsobanyaite taken from RRUFF database

Figure 4. Comparison of the measured Raman spectrum (averaged and baseline corrected) formed on the as received $1050 \mathrm{Al}$ sample after 2-week exposure to $1.5 \mu \mathrm{L}$ droplet of ASW and $\mathrm{RH}=84 \pm 4 \%$ and $\mathrm{T}=30 \pm 1{ }^{\circ} \mathrm{C}$ and standard spectrum of dawsonite taken from RRUFF database

Figure 5. Image of corroded TSA on glass sample after 2-week exposure to $1.5 \mu \mathrm{L}$ droplet of ASW and $\mathrm{RH}=84 \pm 4 \%$ and $\mathrm{T}=30 \pm 1{ }^{\circ} \mathrm{C}$; EDX maps of chlorine, sulphur, oxygen, sodium, magnesium, and carbon; Raman maps of felsobanyaite; SEM image of the corroded region under the droplet

Figure 6. Comparison of the measured Raman spectrum (averaged and baseline corrected) formed on the TSA on glass sample after 2-week exposure to $1.5 \mu \mathrm{L}$ droplet of ASW and $\mathrm{RH}=84 \pm 4 \%$ and $\mathrm{T}=30 \pm 1{ }^{\circ} \mathrm{C}$ and standard spectrum of felsobanyaite, alunogen and aluminite taken from RRUFF database.

Figure 7. Image of corroded TSA on glass sample after 2-week exposure to $2.5 \mu \mathrm{L}$ droplet of ASW and $\mathrm{RH}=97 \pm 3 \%$ and $\mathrm{T}=30 \pm 1{ }^{\circ} \mathrm{C}$; EDX maps of oxygen, sulphur, chlorine, magnesium and carbon; Raman maps of felsobanyaite/aluminite; SEM image of the corroded region under the droplet

Figure 8. Comparison of the measured Raman spectrum (averaged and baseline corrected) formed on the TSA on steel sample after 2-week exposure to $2.5 \mu \mathrm{L}$ droplet of ASW and $\mathrm{RH}=97 \pm 3 \%$ and $\mathrm{T}=30 \pm 1{ }^{\circ} \mathrm{C}$, standard spectrum of felsobanyaite taken from RRUFF database and spectrum collected from an uncorroded TSA coating.

Figure 9. Arrays of droplets of ASW on TSA on steel sample, immediately after the completion of 2-week exposure to $\mathrm{RH}=97 \pm 3 \%$ and $\mathrm{T}=30 \pm 1{ }^{\circ} \mathrm{C}$; (a) magnified image of the first droplet from a side view showing its spherical shape, (b) side view of the sample.

Figure 10. Surface roughness of uncorroded TSA coating deposited on steel

Figure 11. The OCP of TSA on steel (orange $\mathrm{x}$ ) and TSA on glass (blue o) in ASW at $25^{\circ} \mathrm{C}$ as a function of time 
Figure 12. Polarisation resistance of TSA on steel (x) and TSA on glass (o) in ASW at $25^{\circ} \mathrm{C}$ as a function of time

Figure 13. The inverse of polarisation resistance of TSA on steel (x) and TSA on glass (o) in $\mathrm{ASW}$ at $25^{\circ} \mathrm{C}$ as a function of time

Figure 14. Tafel plots after 2-day (dotted line) and 7-day (solid line) immersion in ASW at $25^{\circ} \mathrm{C}$; scan rate $1 \mathrm{mV} / \mathrm{s}$

Figure 15. Comparison of the measured Raman spectra (baseline corrected) collected from TSA on steel sample after 32-day immersion in ASW at T $=30 \pm 1{ }^{\circ} \mathrm{C}(\mathrm{A}, \mathrm{B}, \mathrm{C}, \mathrm{D})$ and corresponding images of regions where measurements were taken at. Spectra of felsobanyaite, hydrotalcite, aragonite (taken from RRUFF database) are also shown together with spectrum collected from uncorroded metal. 

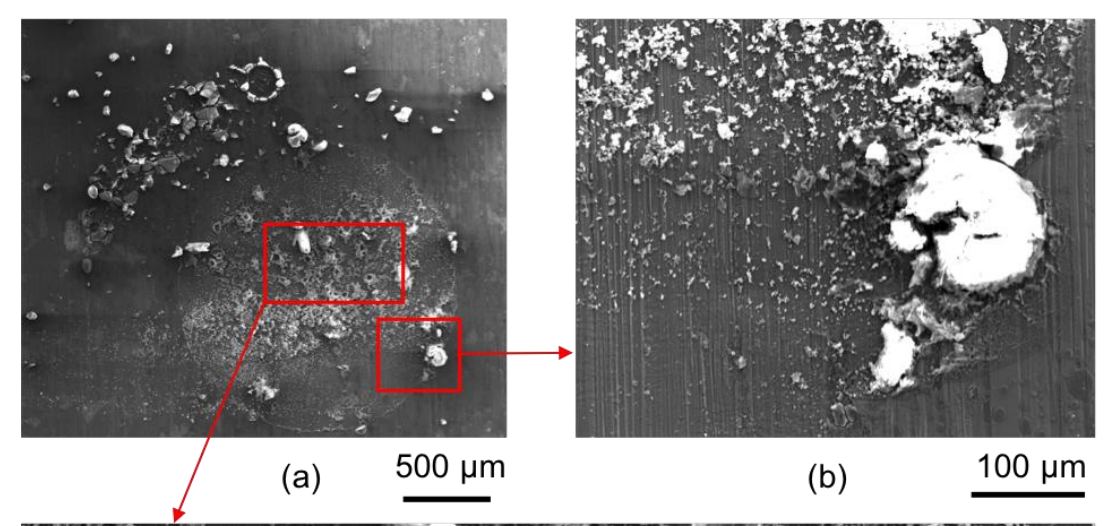

(b) $100 \mu \mathrm{m}$

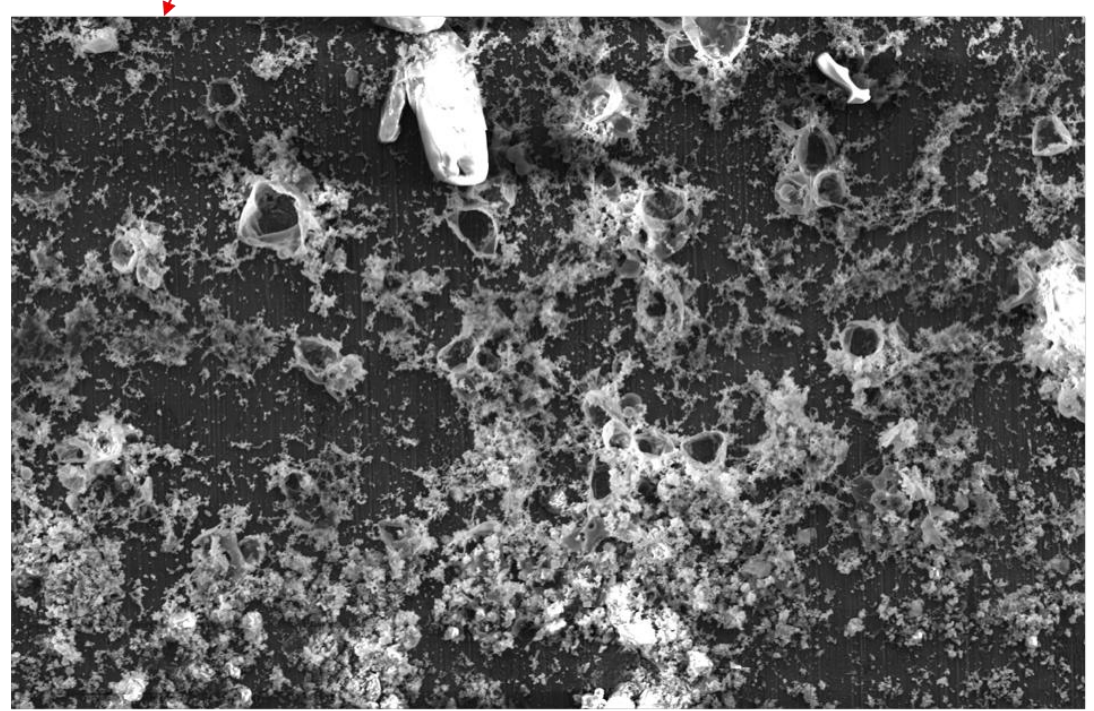

(c)

$100 \mu \mathrm{m}$

Figure 15. 

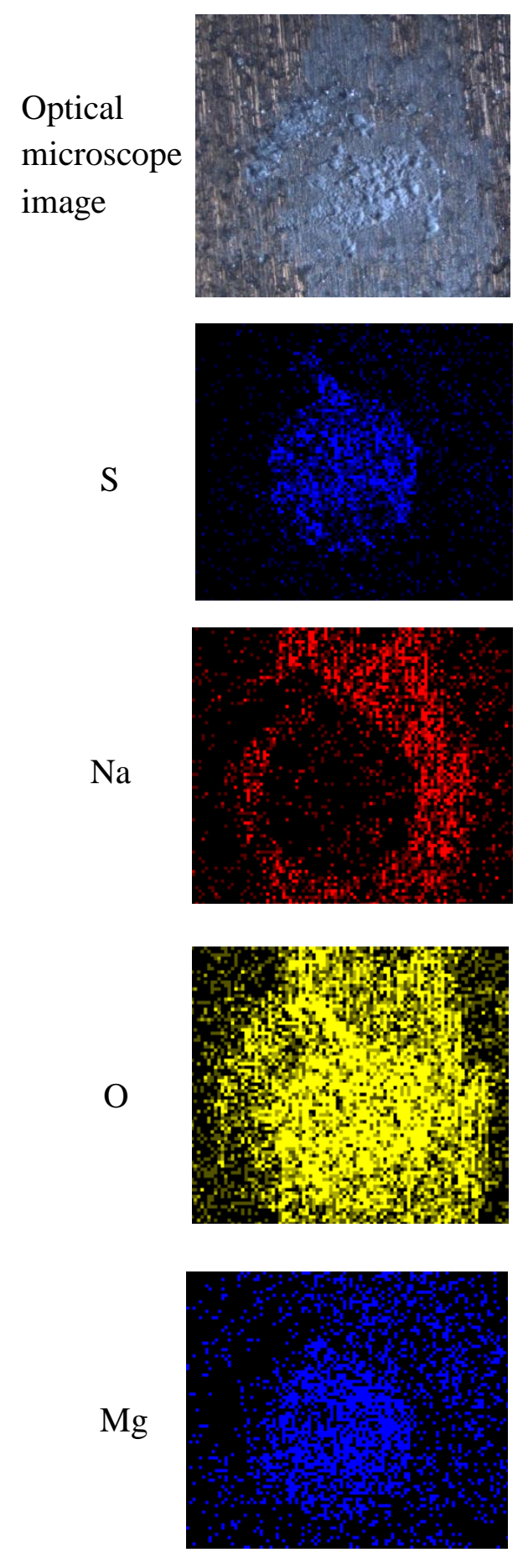

SEM image

\section{Raman map of:}

Felsobanyaite

$\mathrm{Al}_{4}\left(\mathrm{SO}_{4}\right)(\mathrm{OH})_{10} \cdot 4 \mathrm{H}_{2} \mathrm{O}$

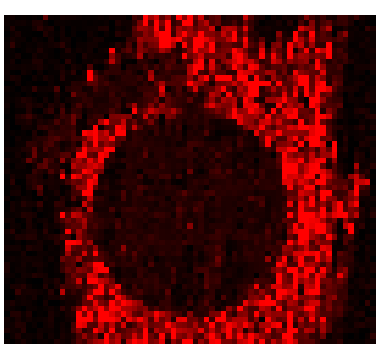

\section{Raman map of:}

Dawsonite

$\mathrm{NaAlCO}_{3}(\mathrm{OH})_{2}$

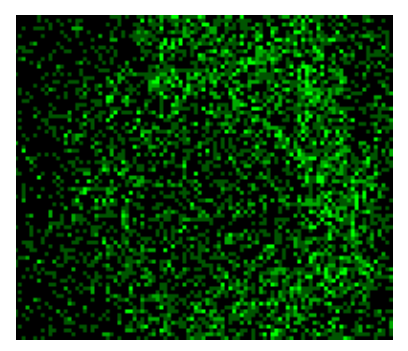

C

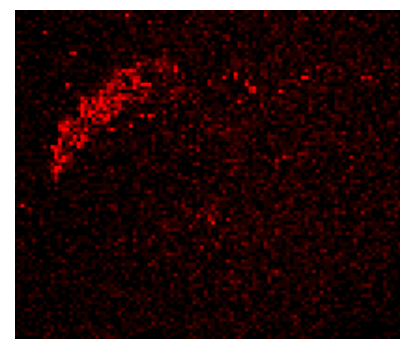

$\mathrm{Cl}$

$2 \mathrm{~mm}$

Figure 16. 


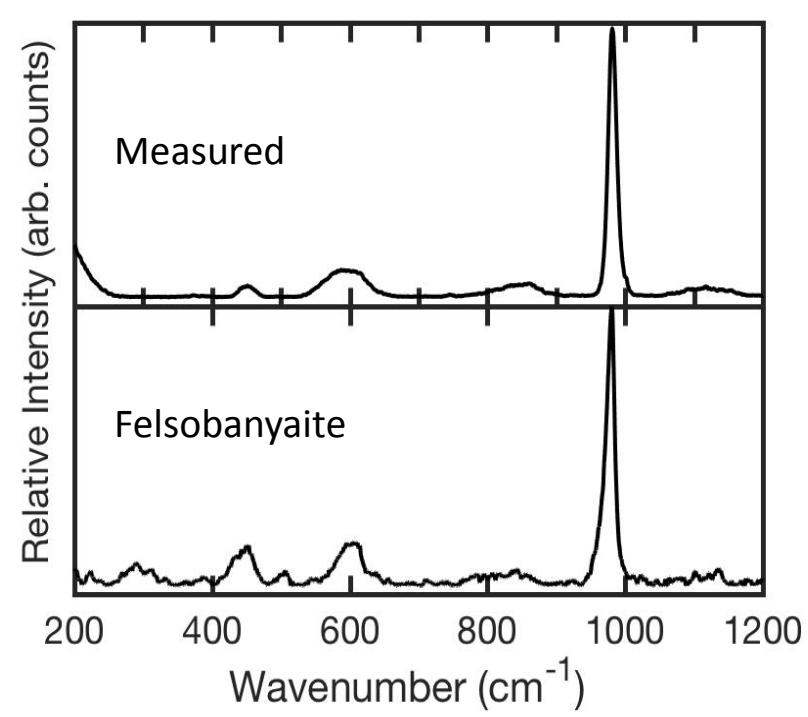

Figure 17.

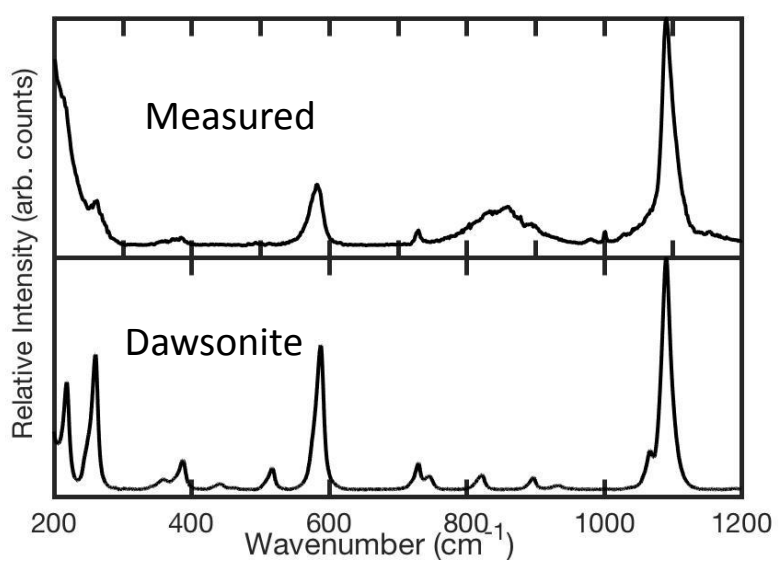

Figure 18. 

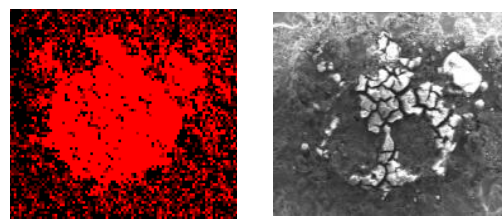

SEM image

S
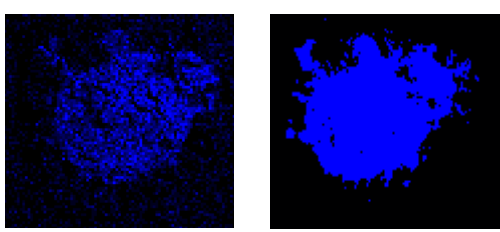

\section{Raman map of:}

felsobanyaite

$\mathrm{Al}_{4}\left(\mathrm{SO}_{4}\right)(\mathrm{OH})_{10} \cdot 4 \mathrm{H}_{2} \mathrm{O}$

$\mathrm{O}$
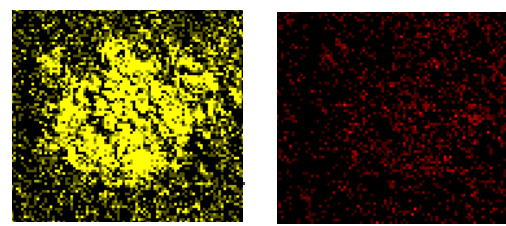

$\mathrm{Na}$
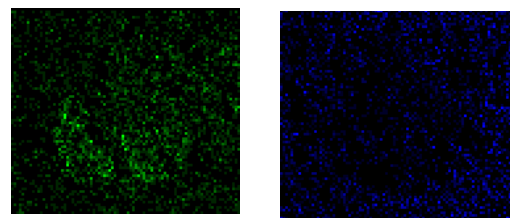

$\mathrm{Mg}$

$1 \mathrm{~mm}$

Figure 19.

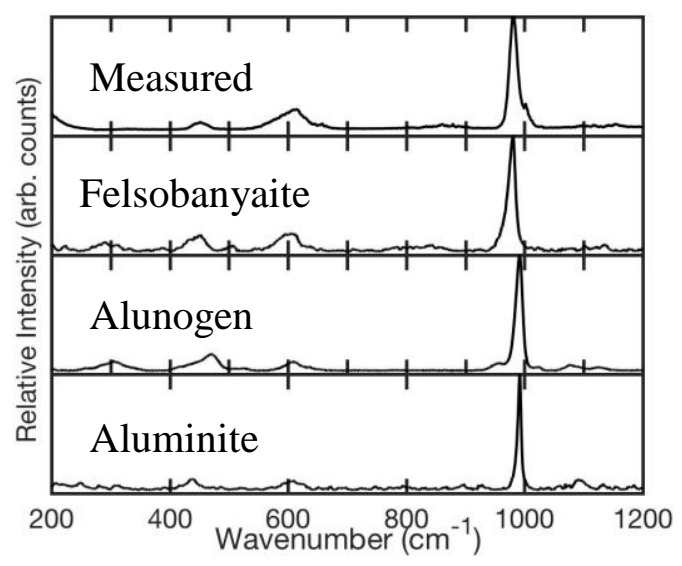

Figure 20 

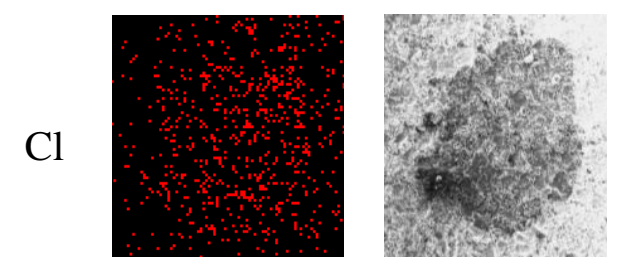

SEM image

S
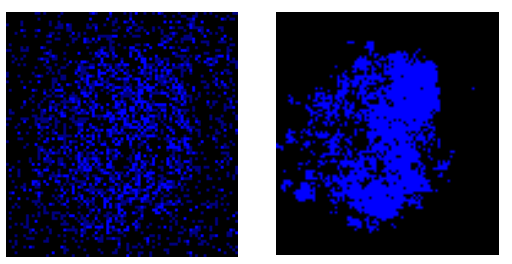

\section{Raman map of:}

felsobanyaite

$\mathrm{Al}_{4}\left(\mathrm{SO}_{4}\right)(\mathrm{OH})_{10} \cdot 4 \mathrm{H}_{2} \mathrm{O}$

$\mathrm{O}$
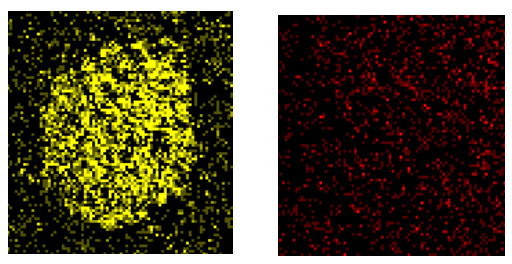

$\mathrm{Na}$
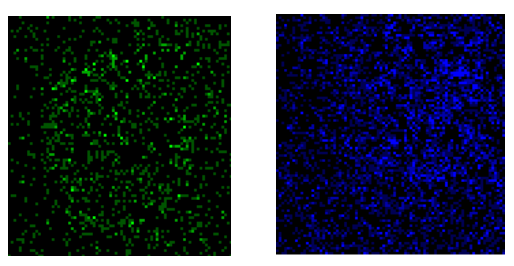

$\mathrm{Mg}$

Figure 21.

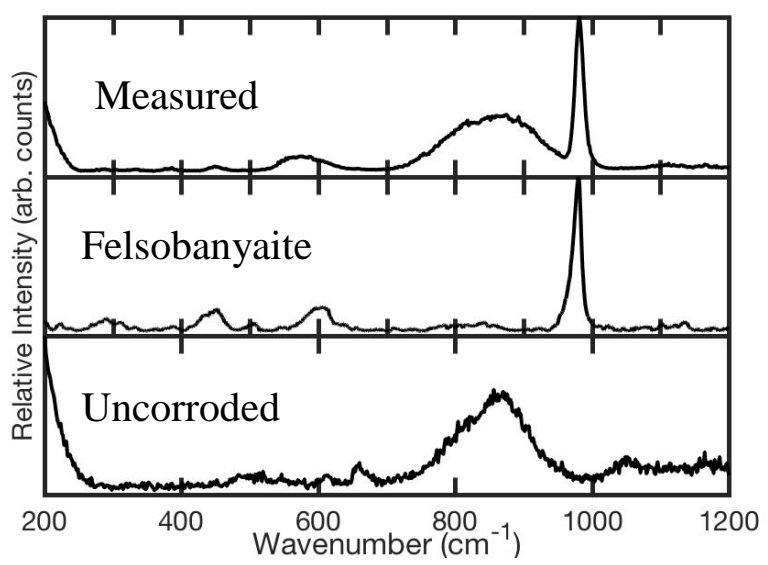

Figure 22. 
(a)

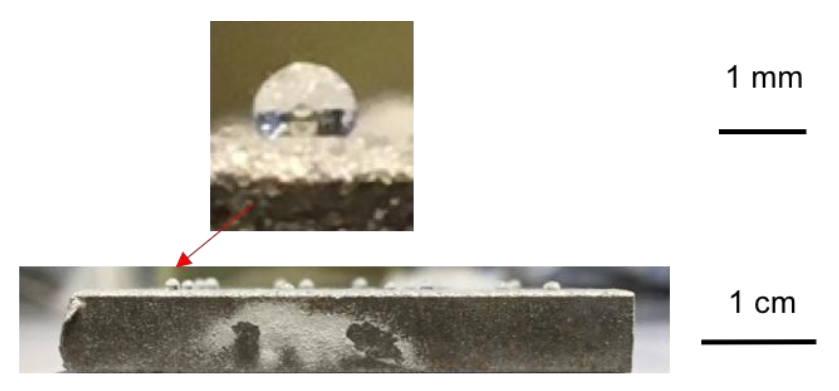

Figure 23.

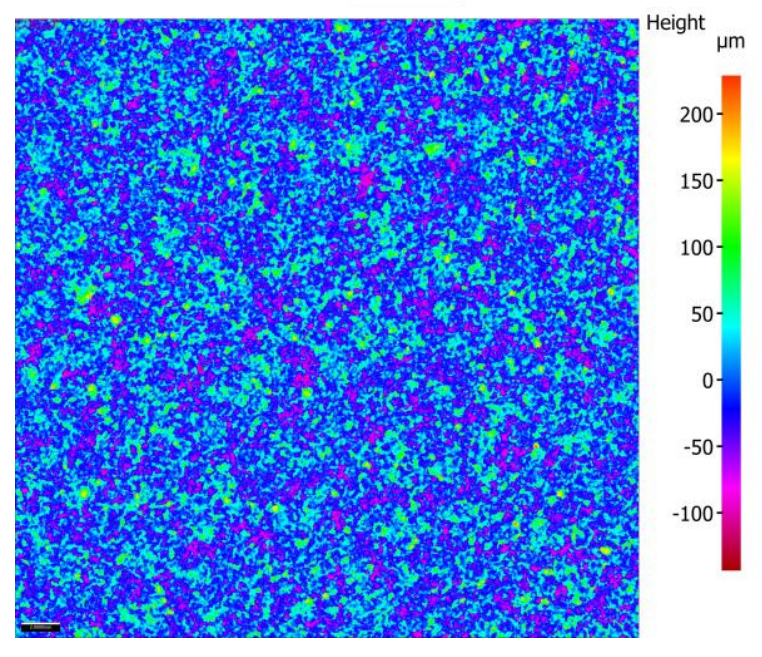

Figure 24.

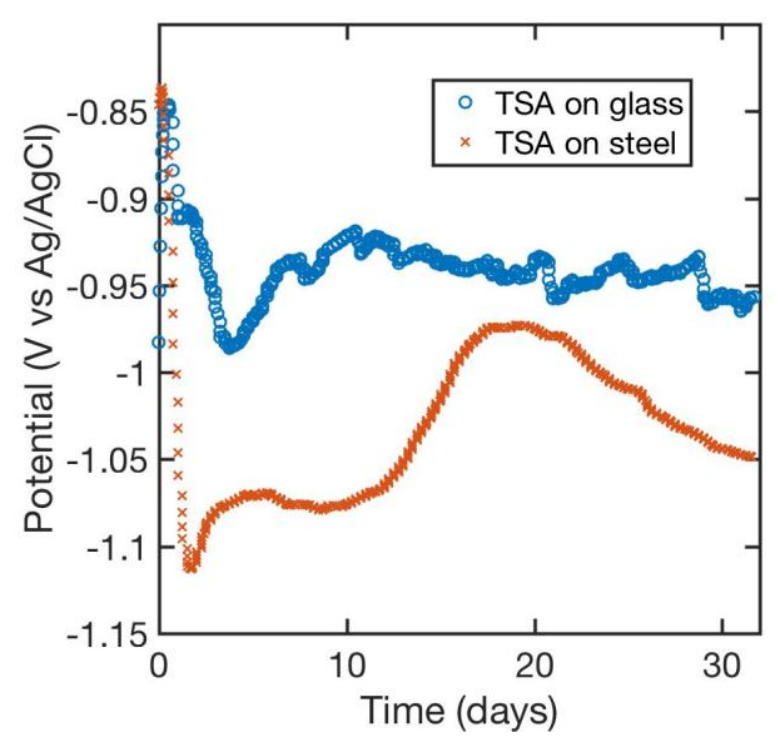

Figure 25. 


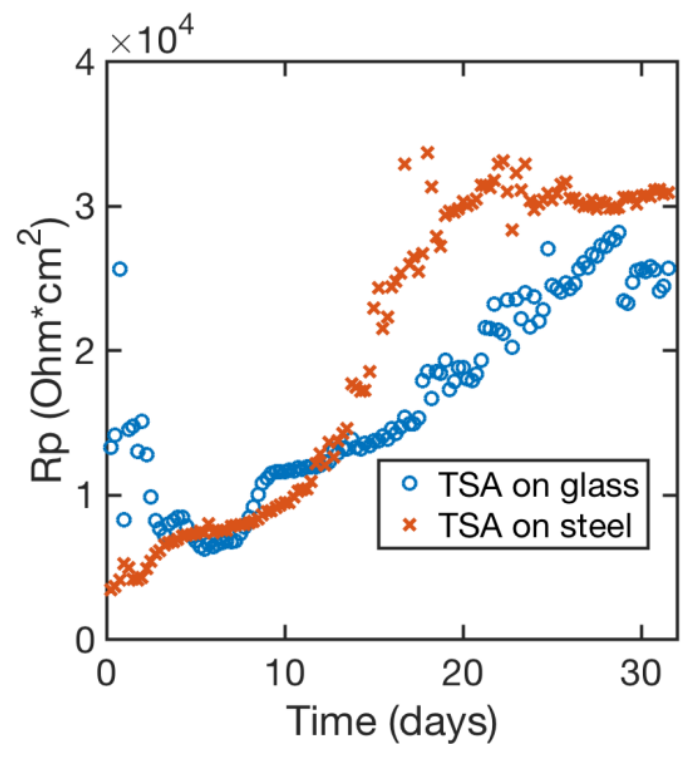

Figure 26.

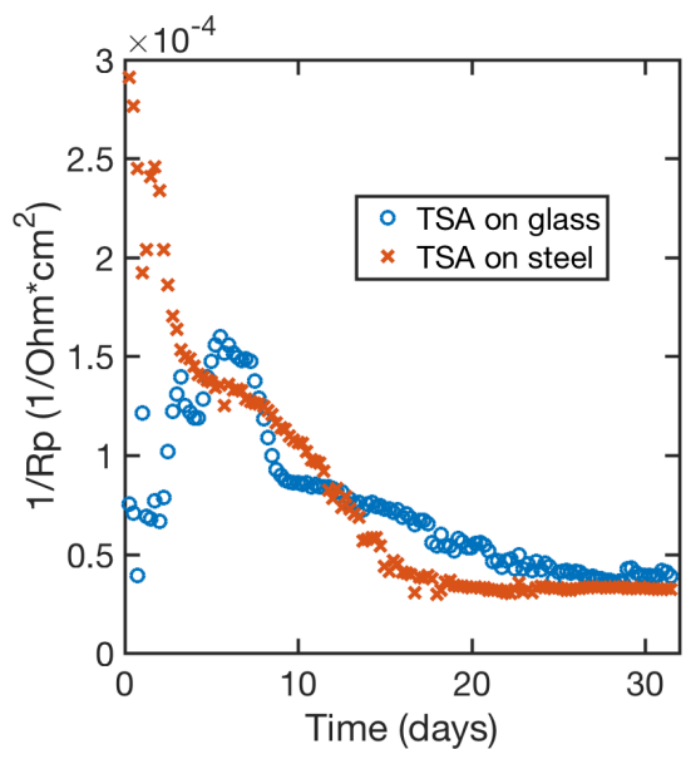

Figure 27. 


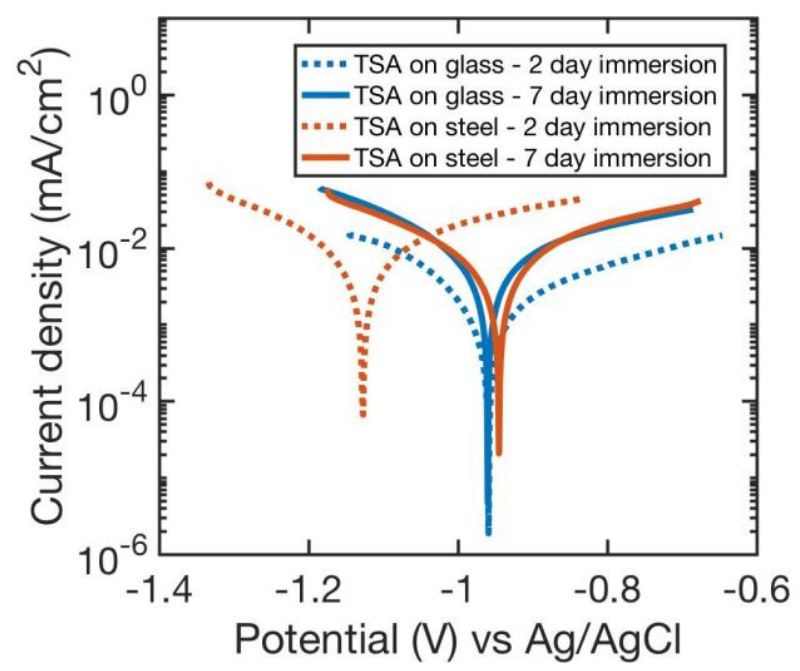

Figure 28.
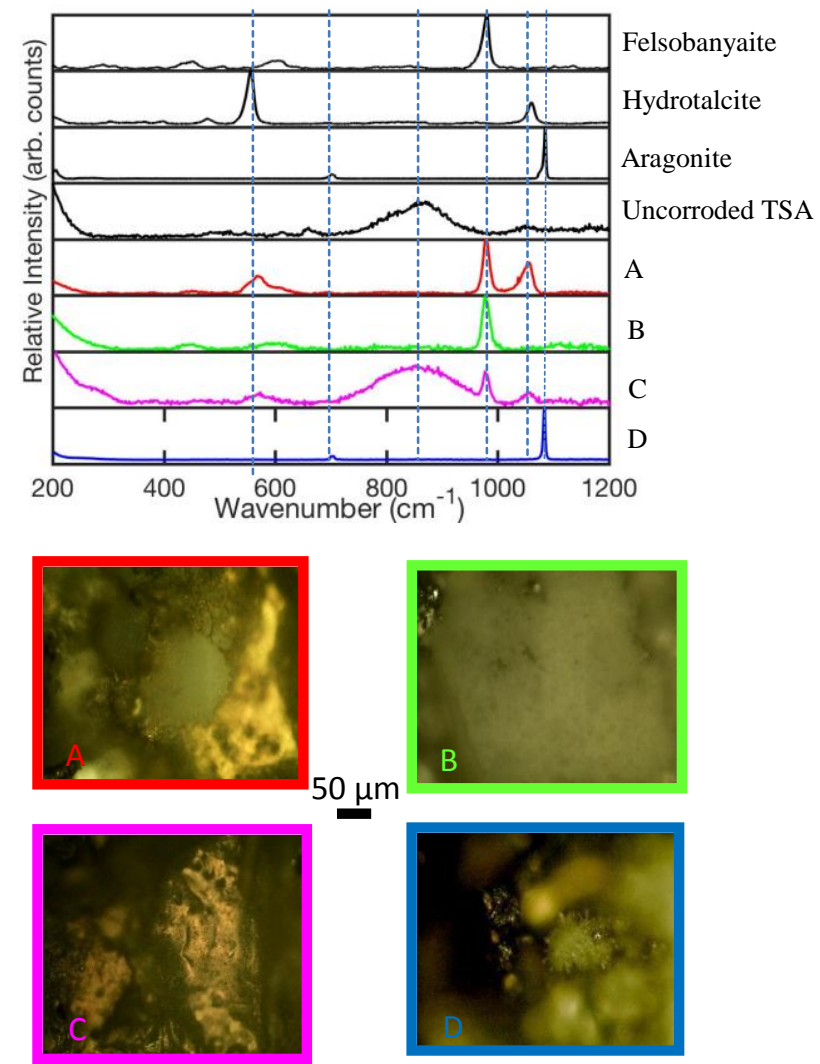

Figure 15. 